\title{
COMPARISON OF SUPEROVULATION IN THE IMMATURE MOUSE AND RAT
}

\author{
EVERETT D. WILSON* AND M. X. ZARROW \\ Department of Biological Sciences, Purdue University, \\ Lafayette, Indiana, U.S.A.
}

(Received 26th May 1961)

\begin{abstract}
Summary. The following factors were found to influence the superovulatory response in immature mice and rats: (1) the dose of pregnant mares' serum (PMS), (2) the dose of human chorionic gonadotropin (HCG), (3) the time interval between PMs and HCG injections, and (4) the time interval between HCG and recovery of maximum number of ova. Dose-response curves for PMS were bell-shaped in both species whereas increasing doses of HCG resulted in a plateau. Histological examination of the ovaries indicated that high doses of PMs resulted in cystic follicles in the rat and preluteinized follicles in the mouse. Both conditions led to a failure to induce superovulation.
\end{abstract}

\section{INTRODUCTION}

The phenomenon of superovulation was described more than 30 years ago (Smith \& Engle, 1927) and has proved to be a useful tool in the study of ovarian response to gonadotropic hormones. It is now evident that both the amount of ovulating hormone (LH) and the amount of follicle-stimulating hormone (FSH) play a major role in ovulation and superovulation (Pincus, 1940; Evans \& Simpson, 1940; Parkes, 1943; Rowlands, 1944; Bodemer, Rumery \& Blandau, 1959) and that FsH may delimit the ability of the follicle to respond to LH (Cole, 1936; Pincus, 1940; Folley \& Malpress, 1944; Dowling, 1949; Willet, McShan \& Meyer, 1952; Payne \& Runser, 1958). Hisaw (1947) emphasized both the need for an adequate amount of FSH and an adequate period for the hormone to act before LH could induce ovulation of the follicle.

The optimum interval between the injection of follicle-stimulating substance (PMs) and the ovulatory dose of chorionic gonadotropin (critical period for PMS) is $56 \mathrm{hr}$ in the rat (Rowlands, 1944; Zarrow, Caldwell, Hafez \& Pincus, 1958), $40 \mathrm{hr}$ in the mouse (Gates \& Runner, 1957; Fowler \& Edwards, 1957), and 54 to $56 \mathrm{hr}$ in the hamster (Bodemer et al., 1959). The dose of ovulating hormone also plays a major role in ovulation and a critical period of 16 to $20 \mathrm{hr}$ is necessary for the hormone to act before the ova can be found in the tubes (Willet, 1953; Casida, 1938; Pincus, 1940; Zarrow et al., 1958).

These studies tend to indicate a marked similarity in the phenomenon of superovulation in the rat and the mouse. However, in the course of a series of

* Present address: Physiological Laboratory, Downing Street, Cambridge, England. 
studies on the possible use of superovulation in the mouse and rat as an assay for $\mathbf{L H}$, a number of similarities and significant differences in this phenomenon was noted between the two species. The present investigation is concerned with the points of similarity and difference and explores the reasons. In addition, dose-response curves for superovulation are compared in both the mouse and rat.

\section{METHODS AND MATERIALS}

Approximately 700 immature Purdue-Swiss mice and 200 immature Purdue rats were used in this study. The animals were obtained on the 20th or 21st day of age and the treatment started on the following day. An attempt was made to select animals of a uniform weight. The gonadotropic hormones used in this study were pregnant mares' serum* (PMs) to stimulate growth of the follicle, human chorionic gonadotropin* (HCG) which possesses LH-like activity, and the luteinizing hormone* (LH) which is extracted from the anterior pituitary gland. The latter two hormones were used to induce ovulation in a previously stimulated ovary. These hormones were dissolved in physiological saline solution and injected subcutaneously in a volume of $0.1 \mathrm{ml}$. Ova counts were obtained by first removing the oviduct and examining this structure under a dissecting microscope. The egg mass is readily accessible in the ampulla of the oviduct which is greatly enlarged and translucent (Burdick \& Whitney, 1941). This distended segment is then punctured and the egg mass expelled (Rowlands, 1942). Hyaluronidase was used occasionally to disperse the cumulus cells and thereby facilitate the counting of ova (Zarrow, Hafez \& Pincus, 1956). Selected ovaries were removed, fixed in Bouin's fluid, sectioned at $10 \mu$, and stained with haematoxylin and eosin. Histological examination was carried out to determine the influence of different doses of PMS, HCG and LH on the ovaries.

\section{RESULTS}

\section{Optimum time requirement between PMS and HCG in mice}

The first step in this series of experiments was the establishment of an optimum time interval between the injection of 10 i.u. of PMs and the injection of $5 \mathrm{i}$.u. of HCG. The ova were counted 20 to $24 \mathrm{hr}$ following the ovulatory dose of HCG and the duration of PMS stimulation prior to the injection of the ovulatory hormone was varied between 10 and $70 \mathrm{hr}$. Only $60 \%$ of the animals, or an average of 4.3 ova, had ovulated after a period of $10 \mathrm{hr}$ (Table 1). The average ova-count increased to 18.0 with $100 \%$ of the animals ovulating after an interval of $20 \mathrm{hr}$ and to $42 \cdot 2$ ova at $30 \mathrm{hr}$. The average number of ova remained relatively constant up to $50 \mathrm{hr}$. At $60 \mathrm{hr}$ after the PMs injection, the ova-count had decreased to 12.5 ova and 12.2 ova at $70 \mathrm{hr}$. The results of this experiment indicate that the optimum length of time for PMs stimulation is between 30 and $50 \mathrm{hr}$. Consequently, an interval of $40 \mathrm{hr}$ was used for the remainder of the

* The HCG $\left(A P L^{R}\right)$ and PMS $\left(\right.$ Equinex $\left.^{\mathbf{R}}\right)$ were obtained through the courtesy of Ayerst Laboratories. Additional supplies of HCG (Follutein ${ }^{R}$ ) were also obtained through the courtesy of Dr Borman, Squibb Institute, New Brunswick, N.J. The LH (227-80) was kindly supplied by Armour Pharmaceutical Co. 
experiments on mice. This experiment was not conducted in the rat since previous work by Rowlands (1944) and Zarrow et al. (1958) indicated that the optimum time interval between the injection of PMS and HCG was $56 \mathrm{hr}$ in the immature rat.

\section{TABLE 1}

EFFECT OF THE TIME INTERVAL BETWEEN THE PMS AND HCG INJEGTIONS ON THE NUMBER OF OVA RELEASED IN THE IMMATURE MOUSE

\begin{tabular}{c|c|c|c|c}
\hline $\begin{array}{c}\text { No. } \\
\text { animals }\end{array}$ & $\begin{array}{c}\text { Mean body } \\
\text { weight }\end{array}$ & $\begin{array}{c}\text { Hr between } \\
\text { PMS and HCG }\end{array}$ & $\begin{array}{c}\text { Av. No. ova } \\
\text { per animal } \\
\pm \text { S.E.* }\end{array}$ & $\begin{array}{c}\text { Ovulation } \\
(\%)\end{array}$ \\
\hline 10 & $11 \cdot 9$ & 10 & $4 \cdot 3 \pm 5 \cdot 6$ & 60 \\
10 & $12 \cdot 9$ & 20 & $18 \cdot 0 \pm 5 \cdot 6$ & 100 \\
10 & $16 \cdot 3$ & 30 & $42 \cdot 2 \pm 5 \cdot 6$ & 100 \\
10 & $13 \cdot 1$ & 32 & $37 \cdot 7 \pm 5 \cdot 6$ & 90 \\
38 & $13 \cdot 4$ & 40 & $44 \cdot 4 \pm \mathbf{4} \cdot 0$ & 100 \\
15 & $15 \cdot 7$ & 44 & $36 \cdot 1 \pm \mathbf{4} \cdot 6$ & 100 \\
10 & $15 \cdot 7$ & 50 & $34 \cdot 8 \pm 5 \cdot 6$ & 100 \\
10 & $14 \cdot 9$ & 60 & $12 \cdot 5 \pm 5 \cdot 6$ & 90 \\
10 & $15 \cdot 5$ & 70 & $12 \cdot 2 \pm 5 \cdot 6$ & 100 \\
\hline
\end{tabular}

* Homogeneity of variance was tested by Bartlett's Test. PMs was held constant at 10 i.u., HCG constant at 5 i.u. Time between HCG injection and autopsy was held constant at 20 to $24 \mathrm{hr}$.

\section{TABLE 2}

EFFECT OF VARIATION IN THE TIME INTERVAL BETWEEN TREATMENT WITH HCG AND AUTOPSY ON OVA COUNT IN THE IMMATURE MOUSE

\begin{tabular}{|c|c|c|c|c|}
\hline $\begin{array}{c}\text { No. } \\
\text { animals }\end{array}$ & $\begin{array}{c}\text { Mean body } \\
\text { weight }\end{array}$ & $\left|\begin{array}{c}\text { Hr between } \\
\text { PMS and } \mathrm{HCG}\end{array}\right|$ & $\begin{array}{c}\text { Av. No. ova } \\
\text { per animal } \\
\pm \text { S.E.* }\end{array}$ & $\begin{array}{c}\text { Ovulation } \\
(\%)\end{array}$ \\
\hline $\begin{array}{r}10 \\
10 \\
10 \\
10 \\
20 \\
20 \\
20 \\
20 \\
15 \\
6\end{array}$ & $\begin{array}{l}12 \cdot 2 \\
12 \cdot 0 \\
12.2 \\
12.9 \\
12 \cdot 0 \\
11.6 \\
13.0 \\
13.4 \\
12.1 \\
14.5\end{array}$ & $\begin{array}{r}8 \\
10 \\
12 \\
14 \\
16 \\
18 \\
20 \\
24 \\
26 \\
30\end{array}$ & $\begin{array}{c}0 \\
0 \\
0 \\
13 \cdot 5 \pm 6 \cdot 5 \\
21 \cdot 6 \pm 6 \cdot 5 \\
38 \cdot 5 \pm 4 \cdot 6 \\
32 \cdot 1 \pm 4 \cdot 6 \\
35 \cdot 6 \pm 4 \cdot 6 \\
37 \cdot 2 \pm 4 \cdot 6 \\
26 \cdot 7 \pm 5 \cdot 3 \\
21 \cdot 7 \pm 8 \cdot 4\end{array}$ & $\begin{array}{r}0 \\
0 \\
90 \\
100 \\
100 \\
100 \\
100 \\
90 \\
100 \\
100\end{array}$ \\
\hline
\end{tabular}

* Homogeneity of variance was tested by Bartlett's Test. The dose of PMS and HCG was held constant at 10 and 5 i.u., respectively, and the time interval between the injection of PMS and HCG was held constant at $40 \mathrm{hr}$.

Optimum time requirement between injection of HCG and presence of ova in oviduct

The second experiment was designed to determine the optimum time necessary to obtain a maximum number of ova following treatment with HCG. The dose of PMS was held constant at 10 i.u. and after an interval of $40 \mathrm{hr}$ 
a constant dose of 5 i.u. of HCG was administered. The time interval between HCG and autopsy was varied from 8 to $30 \mathrm{hr}$. No ova were found in the oviduct at 8 to $10 \mathrm{hr}$ after treatment with HCG but as the interval was increased to $12 \mathrm{hr}$, an average of 13.5 ova was recovered (Table 2). The number of ova increased to 21.6 at $14 \mathrm{hr}$ and reached a peak of 38.5 at $16 \mathrm{hr}$ and remained relatively constant up to $24 \mathrm{hr}$. As the time interval was increased to $26 \mathrm{hr}$, the count dropped to 26.7 ova and by $30 \mathrm{hr}$ the count dropped to 21.7 ova.

The optimum time interval between the injection of HCG and the presence of ova in the oviduct is 16 to $24 \mathrm{hr}$ (Table 2). An interval of from 20 to $24 \mathrm{hr}$ was used for the remainder of the work on mice and rats since previous work had also shown this interval to be optimum for the rat (Zarrow et al., 1958).

Influence of varied doses of PMS and HCG on the ova count in mice

The third experiment was designed to determine the effect of different concentrations of PMS and HCG on the number of ova released. PMS was injected at dose levels of $1,2 \cdot 5,5,10,20,30$ and 40 i.u., followed by HGG. When 1 i.u.

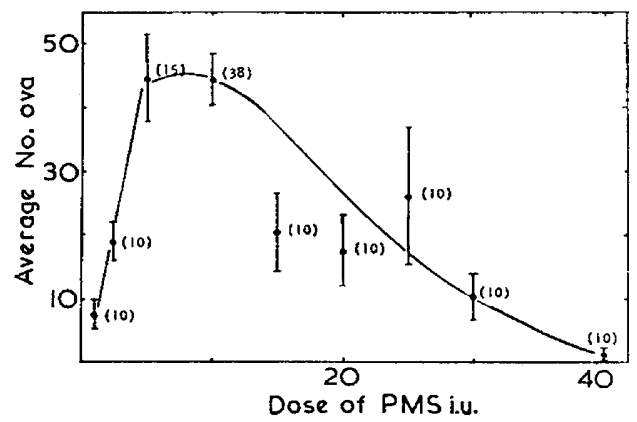

TEXT-FIG. 1. Dose-response curve for PMS in the immature mouse based on the superovulatory response. The treatment with HCG was held constant at 5 i.u.

of PMS was injected, from 4.5 to 8.0 ova were recovered, depending on the dose of HGG administered (Table 3). Ovulation of 4.5 ova in response to 1 i.u. PMS and 1 i.u. HCG compared favourably with 6.3 ova obtained with the same doses by Runner \& Gates (1954). Thus the dose of pms seems to be a limiting factor in determining the number of ova released from the ovary (Text-fig. 1). When the dose of PMS was increased to 2.5 i.u., an average of 5.8 ova was obtained after treatment with 0.5 i.u. HCG and 28.6 ova after treatment with 20 i.u. HCG. In this case, the dose of HCG is also a determining factor in the number of ova released. By doubling the dose of PMs to 5 i.u. a range of 3.4 ova was obtained with 0.5 i.u. HGG and 45.8 ova with 20 i.u. HCG was obtained (Text-fig. 1 and Table 3). With a further increase in dose of PMs to 10 i.u., a low ova count of 13.4 was found following 1 i.u. of HCG and a high of 76.2 ova following $100 \mathrm{i}$.u. of HCG. The ovulatory response to $30 \mathrm{i}$.u. PMS was considerably lower at all dose levels of HCG. The average ova counts were 13.4 following 1.0 i.u. HCG, 10.4 following 5 i.u. HCG, 13.4 following 10 i.u. HCG, and 5.5 following 20 i.u. HCG. Increasing the dose of PMS beyond 10 i.u. caused a gradual decrease in number of ova counted to approximately a zero value at 40 i.u., 
TABLE 3

EFFECT OF VARIOUS DOSES OF PMS AND HGG ON THE SUPEROVULATORY RESPONSE IN THE MOUSE

\begin{tabular}{|c|c|c|c|c|}
\hline $\begin{array}{c}\mathcal{N} o . \\
\text { animals }\end{array}$ & $\begin{array}{c}\text { Dose of } \\
\text { PMS (i.u.) }\end{array}$ & $\begin{array}{c}\text { Dose of } \\
\text { HCG (i.u. })\end{array}$ & $\begin{array}{l}\text { Av. No. ova } \\
\text { per animal } \\
\quad \pm \text { S.E. }\end{array}$ & $\begin{array}{c}\text { Ovulation } \\
(\%)\end{array}$ \\
\hline 5 & $2 \cdot 5$ & .5 & $5 \cdot 8 \pm 3 \cdot 5$ & 60 \\
\hline 9 & 5 & .5 & $3.4 \pm 1.6$ & 44 \\
\hline 12 & 10 & .5 & $19 \cdot 5 \pm 7 \cdot 7$ & 50 \\
\hline 5 & 20 & .5 & & 0 \\
\hline 10 & 1 & 1.0 & $4 \cdot 5 \pm 1 \cdot 0$ & 80 \\
\hline 10 & $2 \cdot 5$ & $\begin{array}{l}1.0 \\
0\end{array}$ & $8 \cdot 4 \pm 2 \cdot 1$ & 80 \\
\hline 15 & $5 \cdot 0$ & 1.0 & $28 \cdot 3 \pm 6 \cdot 8$ & 80 \\
\hline 21 & $10 \cdot 0$ & 1.0 & $13 \cdot 4 \pm 4 \cdot 5$ & 48 \\
\hline 10 & 15 & $\begin{array}{l}1.0 \\
0\end{array}$ & $9 \cdot 4 \pm 2 \cdot 3$ & 100 \\
\hline 10 & 20 & 1.0 & $22 \cdot 3 \pm 11 \cdot 3$ & 50 \\
\hline 10 & 30 & 1.0 & $13 \cdot 4 \pm 9 \cdot 3$ & 60 \\
\hline 5 & 10 & $2 \cdot 5$ & $22 \cdot 2 \pm 12 \cdot 0$ & 80 \\
\hline 10 & 1 & $5 \cdot 0$ & $7 \cdot 6 \pm 2 \cdot 3$ & 80 \\
\hline 10 & $2 \cdot 5$ & $5 \cdot 0$ & $19 \cdot 0 \pm 3 \cdot 0$ & 100 \\
\hline 15 & 5 & $5 \cdot 0$ & $44.5 \pm 6.9$ & 100 \\
\hline 38 & 10 & 5.0 & $44.4 \pm 4 \cdot 0$ & 95 \\
\hline 10 & 15 & $5 \cdot 0$ & $20 \cdot 5 \pm 6 \cdot 1$ & 80 \\
\hline 10 & 20 & $5 \cdot 0$ & $17 \cdot 6 \pm 5 \cdot 6$ & 80 \\
\hline 10 & 25 & 5.0 & $26 \cdot 1 \pm 10 \cdot 9$ & 60 \\
\hline 10 & 30 & $5 \cdot 0$ & $10 \cdot 4 \pm 3 \cdot 6$ & 90 \\
\hline 10 & 40 & $5 \cdot 0$ & $1.3 \pm 1.2$ & 20 \\
\hline 10 & 1 & 10 & $7 \cdot 9 \pm 2 \cdot 0$ & 90 \\
\hline 10 & $2 \cdot 5$ & 10 & $14.4 \pm 5 \cdot 6$ & 50 \\
\hline 25 & 5 & 10 & $29 \cdot 1+4 \cdot 7$ & 96 \\
\hline 26 & 10 & 10 & $33 \cdot 6 \pm 5 \cdot 1$ & 100 \\
\hline 14 & 20 & 10 & $31.8 \pm 10 \cdot 4$ & 94 \\
\hline $\begin{array}{l}17 \\
15\end{array}$ & 30 & 10 & $13.4 \pm 6.9$ & 47 \\
\hline 10 & 40 & 10 & $2.8 \pm 1.5$ & 40 \\
\hline 10 & 1 & 20 & $8.0 \pm .8$ & 100 \\
\hline 5 & $2 \cdot 5$ & 20 & $28 \cdot 6 \pm 5 \cdot 6$ & 100 \\
\hline 15 & 5 & 20 & $45 \cdot 8 \pm 6.9$ & 100 \\
\hline 17 & 10 & 20 & $41 \cdot 1 \pm 8 \cdot 0$ & 100 \\
\hline 10 & 20 & 20 & $18 \cdot 7+5 \cdot 3$ & 80 \\
\hline 15 & 30 & 20 & $5.5 \pm 4.5$ & 40 \\
\hline 15 & 40 & 20 & & 0 \\
\hline 5 & 10 & 30 & $24 \cdot 6 \pm 9 \cdot 1$ & 100 \\
\hline 5 & 20 & 30 & $\begin{array}{r}3.4 \pm 2.3 \\
\end{array}$ & 40 \\
\hline 10 & 5 & 40 & $42 \cdot 7 \pm 6 \cdot 3$ & 100 \\
\hline 17 & 10 & 40 & $37 \cdot 2 \pm 6 \cdot 3$ & 100 \\
\hline 2 & 10 & 50 & $48.0 \pm 1.0$ & 100 \\
\hline$\overline{2}$ & 10 & 80 & $72 \cdot 5+12 \cdot 1$ & 100 \\
\hline 6 & 10 & 100 & $76 \cdot 2 \pm 5 \cdot 4$ & 100 \\
\hline 4 & 10 & 200 & $65.2 \pm 12 \cdot 0$ & 100 \\
\hline 4 & 10 & 400 & $75 \cdot 5 \pm 12.6$ & 100 \\
\hline 2 & 10 & 1000 & $53.5 \pm 8.5$ & 100 \\
\hline
\end{tabular}

Interval between PMS and HCG was held constant at $40 \mathrm{hr}$ and between HCG and autopsy 20 to $24 \mathrm{hr}$.

regardless of the dose of HCG administered. The data for number of ova released as a function of the amount of HCG with PMS held at 5 i.u. were examined for a possible assay (Text-fig. 2). This revealed the existence of a response curve between the dose range of 1 to 5 i.u. of HCG. 
Response of the rat to PMS

In this experiment we have attempted to determine the optimum dose of PMs for maximum ova production in the Wistar rat. The dose of Hag used as the ovulator was maintained at $10 \mathrm{i} . \mathrm{u}$. (Zarrow et al., 1958). With a dose of 5 i.u.

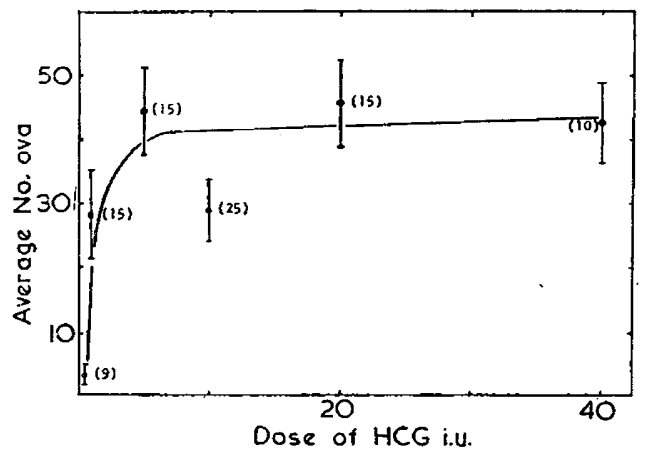

TEXT-FIG. 2 Dose-response curve for HCG in the mouse based on the superovulatory response. The PMS was held constant at 5 i.u.

PMs, an average of 1.6 eggs were ovulated (Table 4). The number of eggs recovered increased with dose to 41.4 ova following treatment with 30 i.u. of PMS. Increasing the dose beyond 50 i.u. produced a marked reduction in the number of ova (Table 4 ). An average of $36 \cdot 6$ ova were obtained after pre-

\section{Table 4}

INFLUENCE OF VARIOUS DOSES OF PMS ON SUPEROVULATION IN THE RAT

\begin{tabular}{|c|c|c|c|}
\hline $\begin{array}{c}\mathcal{N} o . \\
\text { animals }\end{array}$ & $\begin{array}{c}\text { Dose of } \\
\text { PMS }(i . u .)\end{array}$ & $\begin{array}{l}\text { Av. No. ova } \\
\text { per animal } \\
\pm \text { S.E. }\end{array}$ & $\begin{array}{c}\text { Ovtulation } \\
(\%)\end{array}$ \\
\hline $\begin{array}{r}5 \\
5 \\
4 \\
17 \\
5 \\
4 \\
4 \\
5\end{array}$ & $\begin{array}{r}5 \cdot 0 \\
10 \cdot 0 \\
15 \cdot 0 \\
30 \cdot 0 \\
50 \cdot 0 \\
75 \cdot 0 \\
100 \cdot 0 \\
150 \cdot 0\end{array}$ & $\begin{array}{r}1 \cdot 6 \pm \cdot 6 \\
23 \cdot 8 \pm 3 \cdot 5 \\
32 \cdot 7 \pm 7 \cdot 8 \\
41 \cdot 4 \pm 5 \cdot 5 \\
36 \cdot 6 \pm 6 \cdot 8 \\
5 \cdot 7 \pm 1 \cdot 1 \\
1 \cdot 7 \pm 1 \cdot 7 \\
0\end{array}$ & $\begin{array}{r}60 \\
100 \\
100 \\
100 \\
100 \\
100 \\
25 \\
0\end{array}$ \\
\hline
\end{tabular}

Ovulatory dose of HCG was constant at 10 i.u. The interval between PMS and HCG injections was $56 \mathrm{hr}$ and the interval between HCG and autopsy was held constant at 20 to $24 \mathrm{hr}$.

treatment with 50 i.u. PMS, $5 \cdot 7$ with 75 i.u. PMs and no ova were obtained with 150 i.u. PMs.

The results of this part of the experiment indicate that the rat responds to PMS very nearly the same as does the mouse. However, the slope of the doseresponse curve is much steeper in the mouse. 
Response of the rat to varying doses of $H C G$

The optimal dose of 30 i.u. of PMS was held constant for all rats in this experiment and the dose of HCG ranged from $0.5 \mathrm{i} . \mathrm{u}$. to $160 \mathrm{i}$.u. A dose of $0.5 \mathrm{i}$.u. was insufficient to induce any ovulation. The minimal dose appeared to be 1 i.u. which induced $50 \%$ of the animals to ovulate an average of 6.1 ova (Table 5). Maximum ovulation ( 55.8 ova) was obtained with a dose of 5 i.u. The dose of HCG was increased up to $160 \mathrm{i}$.u. without producing any appreciable change in the ova count.

Influence of varied doses of $L H$ following a constant dose of $P M S$ on the number of ova ovulated in mice

This experiment was designed to develop a dose-response curve for LH. In this study, the priming dose of PMS was maintained at 10 i.u., and the dose

TABLE 5

INFLUENCE OF VARIOUS DOSES OF HCG ON SUPEROVULATION IN THE RAT

\begin{tabular}{c|c|c|c}
\hline $\begin{array}{c}\text { No. } \\
\text { animals }\end{array}$ & $\begin{array}{c}\text { Dose of } \\
\text { HcG }(i . u .)\end{array}$ & $\begin{array}{c}\text { Av. No. ova } \\
\text { per animal } \\
\pm \text { S.E. }\end{array}$ & $\begin{array}{c}\text { Ovulation } \\
(\%)\end{array}$ \\
\hline 6 & .5 & 0 & 0 \\
10 & $1 \cdot 0$ & $6 \cdot 1 \pm 3 \cdot 3$ & 50 \\
10 & $2 \cdot 0$ & $16 \cdot 6 \pm 9 \cdot 4$ & 40 \\
10 & $5 \cdot 0$ & $55 \cdot 8 \pm 8 \cdot 4$ & 100 \\
17 & $10 \cdot 0$ & $41 \cdot 4 \pm 5 \cdot 5$ & 100 \\
10 & 20.0 & $33 \cdot 6 \pm 8 \cdot 8$ & 100 \\
10 & 40.0 & $38 \cdot 8 \pm 7 \cdot 7$ & 90 \\
10 & 80.0 & $45 \cdot 0 \pm 8 \cdot 2$ & 90 \\
10 & $160 \cdot 0$ & $44 \cdot 2 \pm 10 \cdot 1$ & 90 \\
\hline
\end{tabular}

Dose of PMs was constant at 30 i.u. The interval between PMS and HCG injections was $56 \mathrm{hr}$ and 20 to $24 \mathrm{hr}$ between HCG and autopsy.

of LH was varied over a range of 1 to $320 \mu$ (Table 6). The smaller doses of LH ( 1 and $2.5 \mu \mathrm{g})$ were insufficient to induce any ovulation in these immature mice. The first ovulations were observed in animals receiving $5 \mu \mathrm{g}$. The average ova-count increased from the $26 \cdot 1$ ova at $5 \mu \mathrm{g}$ to $35 \cdot 1$ ova at $10 \mu \mathrm{g}$ and 47.4 ova at $20 \mu \mathrm{g}$. The ova-count remained at this level up to and including the highest dose $(320 \mathrm{\mu g})$ tested. The minimal effective dose is between 2.5 and $5 \mathrm{mg}$.

Response of rats to various doses of LH (Armour Lot \#227-80)

The dose of PMs for this part of the experiment was held constant at 30 i.u. The ova-count was extremely variable, however, $2.5 \mu \mathrm{g}$ seemed to be the minimal effective dose (Table 7). Only one out of nine animals ovulated at this level. The slope of the curve is much flatter than that seen after HCG injections, also the maximum number of ova released is much less. Only 29.8 ova were recovered with a dose of $80 \mathrm{\mu g}$. Increasing the dose to $160 \mathrm{\mu g}$ has no appreciable effect on the egg count. 
Histological examination of the ovaries

Histological studies were carried out on the ovaries of mice and rats following specific treatment with the gonadotropins. The initial study was concerned with the question as to why increasing doses of PMS (40 i.u) in the mouse failed to give superovulation regardless of the dose of HGG. Pl. 1, Fig. I shows a cross-section of the ovary of a normal immature mouse and may be compared with the ovary

TABle 6

EFFECT OF VARIOUS DOSES OF LH ON THE SUPEROVULATORY RESPONSE

\begin{tabular}{c|c|c|c}
\hline $\begin{array}{c}\text { No. } \\
\text { animals }\end{array}$ & $\begin{array}{c}\text { Dose of } \\
\text { LH ( } \mathrm{\mu g})\end{array}$ & $\begin{array}{c}\text { Av. No. ova } \\
\text { per animal } \\
\pm \text { S.E. }\end{array}$ & $\begin{array}{c}\text { Ovulation } \\
(\%)\end{array}$ \\
\cline { 2 - 3 } & 1 & 0 & 0 \\
7 & $2 \cdot 5$ & 0 & 0 \\
8 & 5 & $26 \cdot 1 \pm 7 \cdot 8$ & 100 \\
8 & 10 & $35 \cdot 1 \pm 6 \cdot 9$ & 100 \\
8 & 20 & $47 \cdot 4 \pm 7 \cdot 0$ & 100 \\
9 & 40 & $47 \cdot 1 \pm 5 \cdot 8$ & 100 \\
9 & 80 & $46 \cdot 6 \pm 6 \cdot 1$ & 100 \\
11 & 160 & $36 \cdot 3 \pm 3 \cdot 6$ & 100 \\
5 & 320 & $57 \cdot 6 \pm 15 \cdot 7$ & 100 \\
\hline
\end{tabular}

Interval between PMS and LH was constant at $40 \mathrm{hr}$ and between LH and autopsy 20 to $24 \mathrm{hr}$. The PMS was held constant at 10 i.u.

TABLE 7

INFLUENCE OF VARIOUS DOSES OF LH ON SUPEROVULATION IN THE RAT

\begin{tabular}{c|c|c|c}
\hline $\begin{array}{c}\text { No. } \\
\text { animals }\end{array}$ & $\begin{array}{c}\text { Dose of } \\
\mathrm{LH}(\mu \mathrm{g})\end{array}$ & $\begin{array}{c}\text { Av. No. ova } \\
\text { per animal } \\
\pm \text { S.E. }\end{array}$ & $\begin{array}{c}\text { Ovulation } \\
(\%)\end{array}$ \\
\hline 9 & $2 \cdot 5$ & $\cdot 8 \pm \cdot 8$ & $11 \cdot 1$ \\
12 & 10 & $11 \cdot 0 \pm 6 \cdot 5$ & $33 \cdot 3$ \\
9 & 20 & $22 \cdot 3 \pm 6 \cdot 9$ & $66 \cdot 6$ \\
15 & 40 & $17 \cdot 1 \pm 7 \cdot 0$ & $66 \cdot 6$ \\
7 & 80 & $29 \cdot 8 \pm 6 \cdot 8$ & 100 \\
10 & 160 & $21 \cdot 5 \pm 5 \cdot 5$ & 90 \\
\hline
\end{tabular}

Dose of PMS was constant at $30 \mathrm{i} . \mathrm{u}$. The interval between PMS and LH injections was $56 \mathrm{hr}$ and 20 to $24 \mathrm{hr}$ between LH and autopsy.

of an immature mouse injected with 40 i.u. of PMS and 5 i.u. of HCG (PI. 1, Fig. 2a). This animal ovulated only four eggs. It can be seen that the follicles are of approximately normal size in the treated animal. However, the granulosa layer is definitely thicker than normal and shows numerous mitotic figures (Pl. 1, Fig. 2b). The interstitial tissue also appears denser although no apparent stimulation of the theca interna is present. It should also be pointed out that 
the values given for the number of ova released are averages and in a group of fifteen or twenty mice following treatment with the optimal dose of PMs ( 5 to 10 i.u.) and 30 i.u. of HCG, several of the animals may ovulate from zero to five ova as compared to an average release of approximately forty ova for the entire group. In this instance, intense luteinization is present with the resultant entrapping of the ova (Pl. 1, Fig. 3).

In the rat, however, high doses of PMs ( 75 i.u.) followed by HCG fail to induce good superovulation due to the formation of large cystic follicles. The granulosa cells appear to degenerate, the follicles are enlarged and filled with fluid and a considerable amount of luteinization is present in the thecal cell layer (PI. 1, Fig. 4).

\section{DISCUSSION}

Superovulation can be induced consistently in immature mice or rats if certain variables are considered and maintained in a proper balance. A comparison

\section{TABLe 8}

COMPARISON OF HORMONAL AND TIME FACTORS FOR SUPEROVULATION IN IMMATURE MICE AND RATS

\begin{tabular}{|c|c|c|}
\hline \multirow{2}{*}{ Treatment } & \multicolumn{2}{|c|}{$\begin{array}{c}\text { Dose or time for optimum response and ovarian } \\
\text { reaction in }\end{array}$} \\
\hline & Mice & Rats \\
\hline $\begin{array}{l}\text { PMS } \\
\text { HCG } \\
\text { LH } \\
\text { Interval between PMS and HCG } \\
\text { Interval HCG to counting of ova } \\
\text { PMS } \\
\text { High doses leading to failure } \\
\quad \text { of superovulation }\end{array}$ & $\begin{array}{l}5 \text { to } 10 \mathrm{i} . \mathrm{u} . \\
5 \text { to } 10 \mathrm{i} . \mathrm{u} . \\
20 \mathrm{\mu g} \\
40 \mathrm{hr} \\
16 \text { to } 24 \mathrm{hr} \\
\text { hyperplasia of } \\
\text { zona granulosa } \\
\text { preluteinization }\end{array}$ & $\begin{array}{c}30 \mathrm{i} . \mathrm{u} . \\
5 \text { to } 10 \mathrm{i} . \mathrm{u} . \\
20 \mu \mathrm{\mu g} \\
56 \mathrm{hr} \\
18 \text { to } 24 \mathrm{hr}\end{array}$ \\
\hline
\end{tabular}

of the five variables studied in this report may be seen in Table 8 . The first factor studied was the time interval between HCG injection and autopsy which would produce maximum results. A maximum number of 38.5 ova (Table 2) was recovered from mice at $16 \mathrm{hr}$ following the injection of HCG. The ova-count remained relatively constant until $26 \mathrm{hr}$ had elapsed following the injection of HCG. At this time, the egg mass (ova and cumulus cells) began to degenerate thus making the denuded ova very difficult to count. Ova were not present in the oviduct when the interval was reduced to $10 \mathrm{hr}$ or below. Comparable results have been published for both mice (Runner \& Palm, 1953) and rats (Zarrow et al., 1958).

The second variable studied was the time interval between PMs injections and HCG injections (Table 1). From our results, the 10-hr interval first used seemed to be of insufficient duration to allow for maximum follicular stimulation. A period of 30 to $50 \mathrm{hr}$ was required for the maximum stimulation with 
PLATE 1
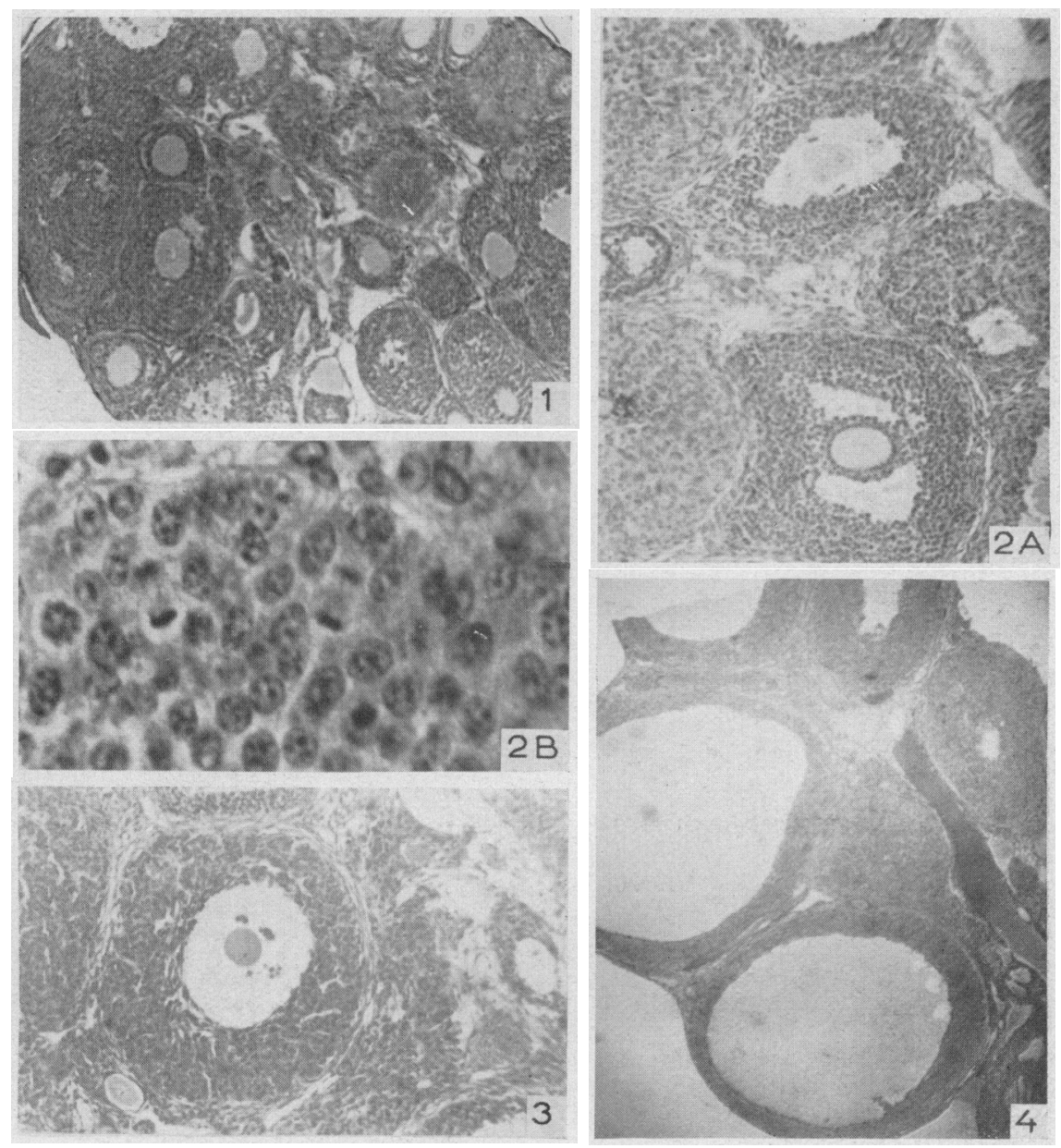

FIG. 1. Normal immature mouse ovary. $10 \times$.

Fig. 2a. Cross-section of an ovary from a mouse that had received 40 i.u. PMs followed $40 \mathrm{hr}$ later by a dose of $5 \mathrm{i}$.u. HCG. This ovary ovulated four ova. $20 \times$. The granulosa layer is thicker than normal.

Fig. 2b. Numerous mitotic figures were present in the granulosa and interstitial tissue. $970 \times$.

FIG. 3. Cross-section of an ovary from a mouse treated with 10 i.u. PMS and 30 i.u. HCG. Intense luteinization has occurred entrapping the ovum. $20 \times$.

FIG. 4. A section of a rat ovary that had becn treated with $75 \mathrm{i}$.u. PMs followed in $56 \mathrm{hr}$ by a dose of 10 i.u. HCG and killed $20 \mathrm{hr}$ following the ovulatory injection. Large cystic follicles are clearly evident. $20 \times$. 
PMs to occur. This is in agreement with the findings of Fowler \& Edwards (1957). There was a marked reduction in number of eggs ovulated after a period of $60 \mathrm{hr}$. By this time, atresia of certain follicles had begun (Rowlands \& Williams, 1943). This time interval has been reported to be $56 \mathrm{hr}$ in the rat (Rowlands, 1944).

The third factor is the amount of PMs administered in a single injection which is necessary to produce maximum follicular stimulation. Hisaw (1947) stated that all the follicles are not equally responsive, and that small doses of PMS may affect only the larger, more mature follicles. Large doses on the other hand affect smaller follicles and cause a rapid maturation, thus increasing the number of follicles capable of being ovulated. The maximum number of ova were recovered from mice receiving between 5 and 10 i.u. of PMS and from rats receiving 30 i.u. PMS. If the dose of PMS is sufficiently large, it appears to overstimulate follicular growth in both mice and rats and in some way causes the formation of cystic follicles in the rat (Rowlands, 1944). This has also been shown to be the case in hamsters (Bodemer et al., 1959). In mice, on the other hand, the follicles become refractory to the ovulating hormone if pretreated with large doses of PMS as indicated by the lack of ovulation in these animals. These follicles were of normal size and filled with an eosin-staining material. The granulosa-cell layer is thickened, with the ovum solidly embedded in the cumulus oophorus. The theca interna does not appear to have received any stimulation (J. A. Green, personal communication, 1960).

The fourth factor is the amount of HCG which is given in a single subcutaneous dose. Fowler \& Edwards (1947) have shown that in pregnant and mature mice superovulation is dependent only on the dose of PMS. They also stated that a small dose of HCG is as effective as is a larger one. From our data, it is quite clear that for a given dose of PMs in immature mice or rats a sigmoid dose-response curve can be obtained with HCG. There is some evidence that high doses of HCG in mice will induce a premature luteinization of certain follicles. These follicles are characterized by intense luteinization of the granulosa-cell layer (J. A. Green, personal communication, 1960). The entrapped ova are usually necrotic and floating free within the follicle. There also appears to be a proliferation of the interstitial tissue (J. A. Green, personal communication, 1960). Perhaps these follicles were not sufficiently mature at the time of HCG injection. Finally, luteinizing hormone was shown to produce ovulation as well as HCG in mice; however, the dose range of LH was considerably lower than those of HCG. High doses of LH were never shown to cause sufficient preluteinization to entrap the ova thus inhibiting ovulation. It is interesting to note that in the rat the average number of ova released following LH is much less than when HGG is used as the ovulator. Perhaps HGG is a better ovulating substance than the naturally occurring LH.

\section{ACKNOWLEDGMENTS}

This investigation was aided in part by a grant from the Purdue Research Foundation (PRF1837) and a grant-in-aid from the American Society of Sterility. 
Bodemer, C. W., Rumery, R. E. \& Blandau, R. J. (1959) Studies on induced ovulation in the intact immature hamster. Fertil. \& Steril. 10, 350.

Burdick, H. O. \& WhitNEY, R. (1941) Ovulation induced in mice by single injections of Follutein or untreated human pregnancy urine. Amer. F. Physiol. 132, 405.

CAsida, L. E. (1938) The preparation, properties, and use of gonad-stimulating hormones. F. Dairy Sci. 21, 101 .

Cole, H. H. (1936) On the biological properties of mare gonadotropic hormone. Amer. F. Anat. 59, 299.

DowLing, D. F. (1949) Problems of the transplantation of fertilized ova. F. agric. Sci. 39, 374.

Evans, H. M. \& Simpson, M. E. (1940) Experimental superfecundity with pituitary gonadotropins. Endocrinology, 27, 305.

Folley, S. J. \& MALPREss, F. H. (1944) The response of the bovine ovary to pregnant mare's serum and horse pituitary extracts. Proc. roy. Soc. B. 132, 164.

Fowler, R. E. \& EdWARds, R. G. (1957) Induction of superovulation and pregnancy in mature mice by gonadotropins. F. Endocrin. 15, 374.

Gates, A. H. \& RunNer, M. N. (1957) Influence of prepuberal age on number of ova that can be superovulated in the mouse. Anat. Rec. 128, 554.

Hisaw, F. L. (1947) Development of the graafian follicle and ovulation. Physiol. Rev. 27, 95.

PARKES, A. S. (1943) Induction of superovulation and superfecundation in rabbits. F. Endocrin. 3, 168.

PAYNe, R. W. \& Runser, R. H. (1958) The influence of estrogen and androgen on the ovarian response of hypophysectomized immature rats to gonadotropins. Endocrinology, 62, 313.

Pincus, G. (1940) Superovulation in rabbits. Anat. Rec. 77, 1.

Rowlands, I. W. (1942) Collection of eggs from the fallopian tube of a rat. Nature, Lond. 150, 267.

Rowlands, I. W. (1944) The production of ovulation in the immature rat. F. Endocrin. 3, 384.

Rowlands, I. W. \& Williams, P. G. (1943) Production of ovulation in hypophysectomized rats. 7. Endocrin. 3, 310.

Runner, M. N. \& Gates, A. (1954) Sterile obese mothers. F. Hered. 45, 51.

RunNer, M. N. \& PALM, J. (1953) Transplantation and survival of unfertilized ova of the mouse in relation to post-ovulatory age. 7. exp. Zool. 124, 303.

SMith, P. E. \& Engle, E. T. (1927) Experimental evidence regarding the role of the anterior pituitary in the development and regulation of the genital system. Amer. F. Anat. 40, 159.

Willett, E. L., McShan, W. H. \& MEYer, R. K. (1952) Relation of stage of cycle and source of luteinizing hormone to superovulation in dairy cattle. Proc. Soc. exp. Biol., N.Y. 79, 396.

Wirlett, E. L. (1953) Egg transfer and superovulation in farm animals. Iowa State Coll. F. Sci. 28, 83.

Zarrow, M. X., Hafez, E. S. E. \& Pincus, G. (1956) New bioassay for urinary LH. Fed. Proc. 15, 667.

Zarrow, M. X., Caldwell, A. L., Hafez, E. S. E. \& Pincus, G. (1958) Superovulation in the immature rat as a possible assay for LH and HCG. Endocrinology, 63, 748. 